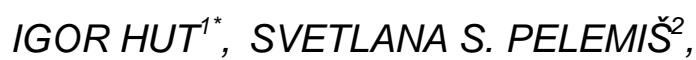
DRAGOLJUB LJ. MIRJANIĆ

${ }^{1}$ Innovation Centre of Faculty of Mechanical Engineering, University of Belgrade,Belgrade, Serbia, ${ }^{2}$ Faculty of Technology, University of East Sarajevo, Zvornik, Republic of Srpska, B\&H;

${ }^{3}$ Academy of Sciences and Arts of Republic of Srpska,Banja Luka, $B \& H$
Scientific paper

UDC:620.92(n)

doi:10.5937/ZasMat1503329H

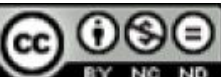

Zastita Materijala 56 (3)

$329-334(2015)$

\title{
Nanomaterials and nanotechnology for sustainable energy
}

\begin{abstract}
The use of nanotechnology to develop a suite of sustainable energy production schemes is one of the most important scientific challenges of the 21st century. The challenge is to design, to synthesize, and to characterize new functional nanomaterials with controllable sizes, shapes, and/or structures.

Nanotechnology is generating a lot of attention these days and therefore building great expectations not only in the academic community but also among investors, the governments, and industry. This paper, explores some of the possible implementations of nanotechnology for new and improved methods of energy conversion, considering a need for this to be done without compromising our environment. Its unique capability to fabricate new structures at atomic scale has already produced novel materials and devices with great potential applications in a wide number of fields. Focus is given to important role of nanomaterials, preparation and characterization some of nanomaterials important for sustainable energy, dye sensitized solar cels and hydrogen production technology.
\end{abstract}

Key words: solar energy, energy conversion, dye sensitized solar cels, hydrogen

\section{INTRODUCTION}

Nanotechnology has played an extremely important role in the design, synthesis, and characterization of various new and novel energy materials and catalysts for processing fuels from fossil fuel resources such as coal, petroleum, and natural gas. Today, fossil fuels still account for $90 \%$ of the world's energy consumption, and their use is expected to peak around the year 2050. The widespread use of fossil fuels is plagued with problems such as the generation of increasingly serious environmental problems, the related climate changes we are witnessing, and the fact that the long-term availability of crude oil is limited. Therefore, it is necessary to develop a suite of sustainable energy sources and energy-storage materials [1].

The use of fossil fuel based technologies is probably one of the main causes of the continuous increase in the pollution and in the concentration of greenhouse gases. Renewable sources must have higher contribution on the energetic matrix in providing more energy available for the humanity in a short period, having low environmental impact.

${ }^{*}$ Corresponding author: Igor Hut, E-mail: igorhut@gmail.com

Paper received: 11. 04. 2015.

Paper accepted: 09. 06. 2015.

Paper is available on the website: www.idk.org.rs/casopis
The interest on the conversion of environmentally friendly energy sources led to the development of several devices that took the advantage of the continuous evolution on several fields of research, which can result in new materials for already developed devices. For instance, the performance of direct methanol fuel cells, a well known technology was improved due to the development of nanomaterials especially designed for the energy conversion process and their evolution allows the use of light to boost the process through a synergic arrangement [2].The synthesis and characterization of new and novel functional nanomaterials with wellcontrolled sizes, shapes, porosities, crystalline phases, and structures are of the utmost importance for breakthroughs in several sustainable energy technologies.

This article provides an overview of how nanoscience and nanotechnology may contribute to the development of more efficient and sustainable energy systems. Nanotechnology is a broad term typically used to describe materials and phenomena at nanoscale, i.e., on the scale of 1 billionth to several tens of billionths of a meter (Fig.1). However, it specifically implies not only the miniaturization but also the precise manipulation of atoms and molecules to design and control the properties of the nanomaterials/ nanosystems. Nanomaterials exhibit distinct size-dependent 
properties in the 1-100 $\mathrm{nm}$ range where quantum phenomena are involved. This is one of the major reasons why nanotechnology has a significant impact on energy conversion and storage. These properties are completely different from those possessed by bulk materials, producing custommade devices with capabilities not found in bulk materials or in nature [3].

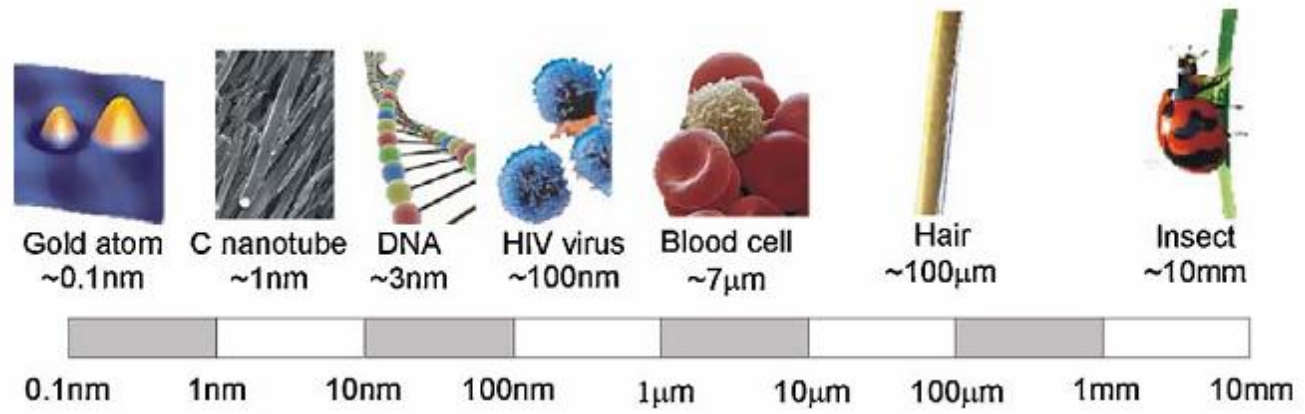

Figure 1 - Length scale and some related example.[4]

Nanoscience and nanotechnology (N\&N), and their merger with surface science (SS), may contribute to the development of a more efficient and sustainable energy system. Like any science or technology field, SS has matured along a time axis that could be visualized as an S-curve (Fig. 2).
In the early stages, research activities were dominated by development of a "tool box" for sample preparation and characterization (e.g. single crystals) as well as theoretical models and calculation schemes [5].

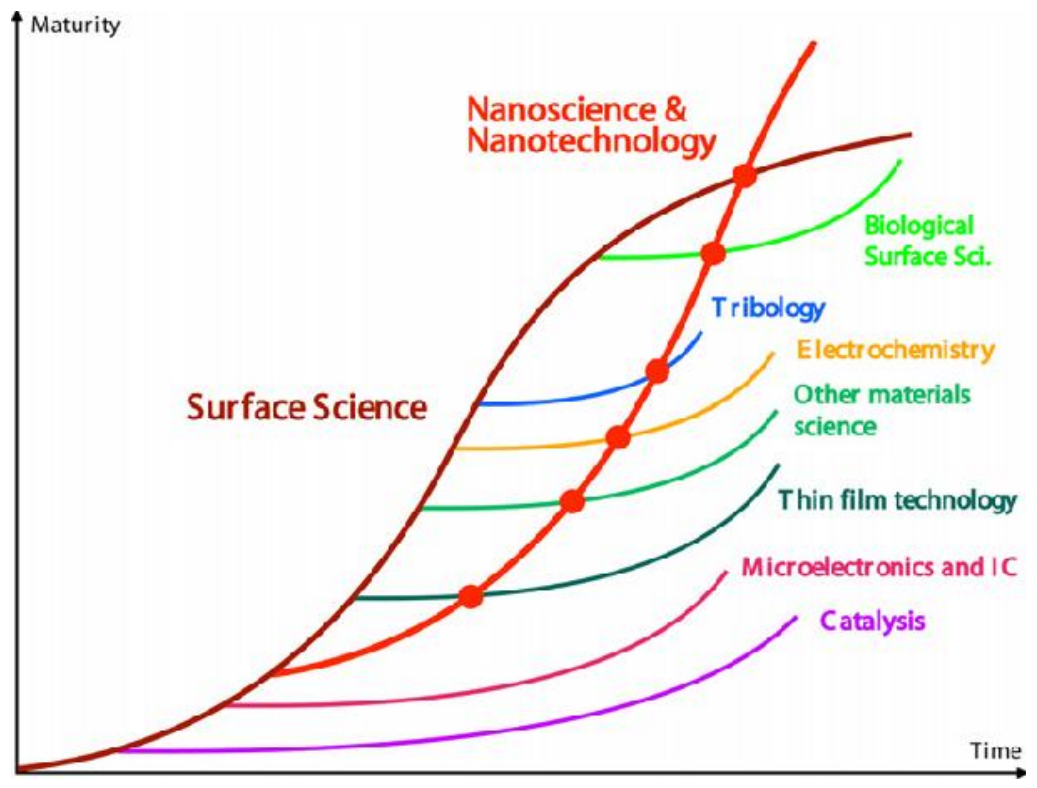

Figure 2 - The historical development of surface science has followed an S-shaped curve, which has served as a basis for the emergence of a large variety of other fields (not the least Nanoscience and Nanotechnology), each of them following its own S-curve. Today, Nanoscience and Nanotechnology influence virtually any field of science and technology, as illustrated by the crossing points [5]

\section{SIZE MATTERS ON THE NANOSCALE}

It is wellknown that the properties of matter change significantly when the size changes from the macroscale to the microscale and from the microscale to the nanoscale. Nanotechnology is often defined as the science and engineering occurring at dimensions of $100 \mathrm{~nm}$ and below. Nanomaterials exhibit distinct size-dependent properties in the $1-100 \mathrm{~nm}$ range where quantum phenomena are involved. This is one of the major reasons why nanotechnology has a significant impact on energy conversion and storage.

Important to remember is that the effects of morphology, structure, and composition of nanomaterials are equally important. It is also important to consider the synergy of size, morphology, structure, and composition for the design and controlled preparation of nano or nanostructured 
materials. The composite materials show an efficient energy transfer in the form of intense photon flux from the metal nanoparticles to neighboring semiconductor particles. Compared to pure semiconductor systems, the improved energy transfer leads to a higher concentration of electron/hole pairs on the semiconductor surface with enhanced photocatalytic rates. Optical properties of the metallic nanoparticles could be tuned on the basis of their size, shape, and composition. This means that a controllable interaction takes place between the metal and semiconductor materials. The rational manipulation of the photoactivity of the composite materials becomes possible in the visible and UV region of the solar spectrum $[1,6]$.

Another example of a size effect is the nickel catalyst used for hydrogen or syngas production via reforming or partial oxidation of methane. Catalytic hydrogen production is an important process for both fossil fuel conversion and for biomass utilization. If cheap hydrogen could be easily produced, many problems in energy production and the environment could be solved. Nickel-based catalysts have been extensively employed and investigated because of the high activity, low cost, and plentiful availability of nickel. However, nickelbased catalysts suffer from a rapid deactivation by coke formation and/or particle aggregation at high temperatures. A high steam/carbon ratio has been applied for the industrial production of hydrogen or syngas over $\mathrm{Ni}$-based catalysts, in order to inhibit coke formation and sustain the catalytic processes. This is not energy efficient because a huge amount of energy is wasted to generate steam. To make and improve nanocatalysts, new and novel catalyst preparation methods are important. For example, a $\mathrm{Rh} \_\mathrm{Ni} @ \mathrm{CeO}_{2}$ catalyst prepared via a virus template for the oxidative steam reforming of ethanol [7]. This novel catalyst preparation method can also be employed to increase the energy or capacity of a Li-ion battery.

\section{NANOTECHNOLOGY FOR SOLAR CELLS AND SOLAR FUELS.}

In the near future nanotechnology may contribute to efficient and low-cost systems for generating, storing, and transporting energy. Materials and structures that are designed and fabricated at the nanoscale level and thin films can offer the potential to produce new devices and processes that may enhance efficiencies and reduce costs in many areas, as solar photovoltaic systems, hydrogen production, fuel cells, solar thermal systems and energy saving technologies as low ecoatings and electrochromic devices for smart windows. It is often overlooked that the portion of contribution of renewable energy sources to the total energy budget will come from all possible forms of applications and sources and to be effective it must be combined with energy saving technological breakthroughs [8]. This energy source can be used in different ways: photovoltaic (PV) technology - which directly converts light into electrical current, solar-thermal systems - used in solar collectors, artificial photosynthesis - which produces either carbohydrates or hydrogen via water splitting, the so-called 'passive solar' technologies, where building design maximizes solar lighting and heating, and even biomass technology - where plants use the solar radiation to drive chemical transformations and create complex carbohydrates, which are used to produce electricity, steam or biofuels. All these energy-related processes and their applications are enclosed in the so-called solar economy $[3,4]$.

PV solar cells enable production of electricity by the means of photoelectric effect. Currently, PV market is based on silicon wafer-based solar cells (thick cells of around 150-300 nm made of crystalline silicon). This technology, classified as the first-generation of photovoltaic cells, accounts for more than $86 \%$ of the global solar cell market. The second-generation of photovoltaic materials is based on the introduction of thin film layers (1-2 $\mathrm{nm}$ ) of semiconductor materials.

The use of nanocrystal quantum dots [9], which are nanoparticles usually made of direct bandgap semiconductors, leads to thin film solar cells based on a silicon or conductive transparent oxide (CTO), like indium-tin-oxide (ITO), substrate with a coating of nanocrystals. Photocatalized decomposition of pollutants at various titania surfaces is of great interest. Electron transfer reactions are at the base of these photoinduced processes and were also the subject of one of the theoretical contributions. The typical scheme of photocatalysis involves harvesting of light photons in a semiconductor (most commonly $\mathrm{TiO}_{2}$ ), and subsequent conversion of these photons to electronic excitations, which then induce the desired chemical reaction on the semiconductor surface [10].

Dye-sensitized solar cells (DSCs) invented by Michael Grätzel became a very popular alternative to silicon based solar cells because of their great potential to convert solar energy into electric energy at low cost. This cell can be made from cheap materials such as inorganic and organic dyes which do not need to be highly pure as is required for silicon wafer.

The dye-sensitized (Gratzel) solar cell (Fig. 3) is perhaps the earliest solar cell directly utilizing nanoscale components for its performance [11]. Here, light absorption takes place predominantly in dye molecules anchored to the surface of 
nanoparticles of a wide bandgap semiconductor, usually $\mathrm{TiO}_{2}$.

The optimization of the dye/ $/ \mathrm{TiO}_{2}$ layer is heavily dependent on nanoscale fabrication and characterization; the $\mathrm{TiO}_{2}$-layer must have a large surface area to incorporate enough dye, but a structure that is thin and open enough to allow for efficient charge transport with minimum losses. Without considering light scattering effects, the optimal film architecture under these conditions is pillar like, with as much surface area as possible (thin pillars) in parallel with the requirement of efficient (low resistance) flow of charge. Achieving sophisticated and pre-designed, and affordable, nanostructures on large-scale surfaces is a challenge.

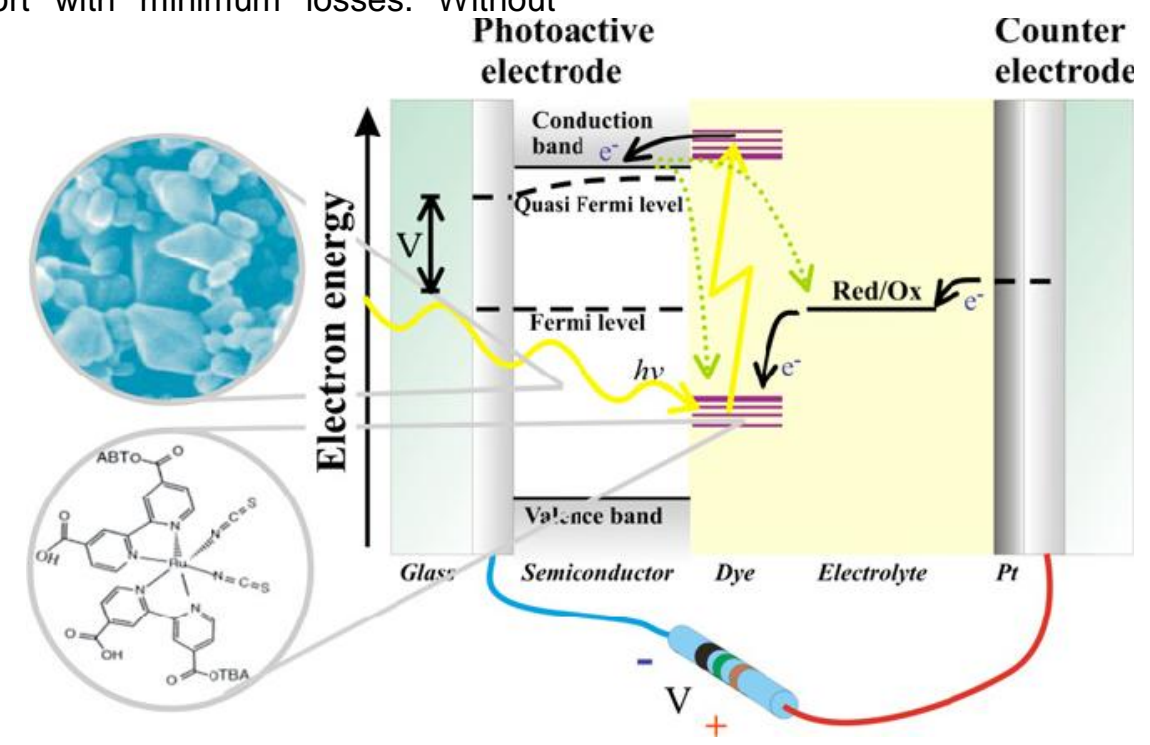

Figure 3 - Schematic of a dye-sensitized solar cell, the performance of which critically depends on nanoscale components. Light absorption occurs in a dye, which is anchored to a nanoporous semiconductor layer [5].

Fuel cells (FC) are electrochemical devices that convert a fuel such as hydrogen or methanol directly to electricity through an electro-catalytic process rather than by combustion, thus potentially yielding much higher energy conversion efficiencies than in conventional combustion engines. With hydrogen as a fuel, the FC is an extremely clean energy converter (but remember that an overall cleanness, based on life cycle analysis (LCA), depends on how hydrogen is produced). At the heart of a FC are the electrodes, on which the actual electro-catalytic conversions occur.

Metal hydrides have for a long time been in focus as one of several alternatives to store hydrogen in a hydrogenbased economy. Two other alternatives are high-pressure gas containers and liquid hydrogen. In metal hydrides one uses the fact that hydrogen uptake in certain metals is exothermic, and furthermore allows saturation uptakes that are close to, or may even exceed, that of liquid hydrogen. The price one has to pay for this storage approach is:

- the heat generated during uptake is usually lost energy and needs to be re-supplied for later release of hydrogen,

- the cost of the storage material,
- the extra weight and volume of the storage material (especially troublesome in mobile applications),

- the added technological complexity of regulating valves and pressure meters etc. (in comparison with e.g. normal gasoline as a fuel),

- the safety precautions.

We will not dwell on all these issues here, but note that there is a renewed interest in hydrogen storage materials, both conventional metal hydrides and new materials such as carbon nanostructures and novel compounds [5].

\section{CHARACTERIZATION OF ENERGY - RELATED NANO OR NANOSTRUCTURED MATERIALS}

To design, to synthesize, and to apply nanomaterials, we need to understand the reaction mechanisms and processes occurring on the surface of nano or nanostructured materials, not only under ultrahigh vacuum (UHV) conditions but under real conditions. Fortunately, progress in vacuum technology and surface-science techniques has led to significant progress in our ability to characterize nanomaterials and especially surface processes. A suite of surface-sensitive techniques such as AES, 
ion scattering spectroscopy (ISS), UV and X-ray photoemission spectroscopy (UPS and XPS), metastable impact electron spectroscopy (MIES), high-resolution electron energy loss spectroscopy (HREELS), infrared reflection absorption spectroscopy (IRAS), low energy electron diffraction (LEED), and scanning probe microscopies (e.g., scanning tunneling microscopy, STM, and atomic force microscopy, AFM) [1].

Model systems consisting of either flat, singlecrystal surfaces or welldefined nanoclusters on surfaces are studied under clean and wellcontrolled, often UHV, conditions. With this approach, an impressive amount of detailed insight into fundamental processes on surfaces has been obtained.

\section{CONCLUSION}

Sustainable energy production, transformation and use are very much needed to maintain the readily and cheap access to energy to the growing and increasingly demanding world population while minimizing the impact on the environment. The novel multifunctional materials produced from the broad and multidisciplinary field that is nowadays called nanotechnology are critical to overcome some of the technological limitations of the various alternatives to the non-renewable energies. Novel multifunctional materials produced trough utilization of nanotechnology offer great improvements in all domains of total energy system, such as transportation and storage of energy. To predict where and how nanotechnology will have the largest impact is not possible. On the short term basis it will probably have more visible influence on existing energy system through introduction of better and more energy efficient materials, on fuel conversion schemes etc.. In farther future nanotechnology will most likely play a major role in the development of truly sustainable solutions like advanced PV systems. For sustainable energy production nanotechnology is one of the fastest growing research fields today.

Nanomaterials serve as energy carriers, absorbents, media for energy transfer, catalysts, converters, and energy pools or vessels for reactions. In all of these applications, the core technology to be developed is the preparation of novel nanomaterials with controllable sizes, shapes, and/or structures. Conventional methods, such as doping, impregnation, and ion exchange, will continue to be used, but there is great opportunity to learn from and try to mimic the nanomaterials and nanomachinery in nature. Many properties of living systems could potentially be harnessed, and methods based on nonequilibrium characteristics will have interesting applications in the future.

The examples above illustrate how N\&N might influence and penetrate into different subsystems of the total energy system, such as primary supply of energy (solar light harvesting, etc.), storage (hydrides, etc.), conversion and use of energy (fuel cells, industrial catalysis, etc.), and abatement of environmental effects (emission and water cleaning).

This evolutionary character and the long time scales call for caution in promising too much too soon - otherwise $N \& N$ runs the risk of facing a serious backlash when (too) high expectations and too far reaching promises are not fulfilled.

\section{Acknowledgements}

This paper was partly financed the Ministry of Science and Technology of the Republic of Srpska.

\section{REFERENCES}

[1] Ch. Liu, U. Burghaus, F. Besenbacher, Zh. Lin Wang (2010) Preparation and Characterization of Nanomaterials for Sustainable Energy Production, NANOFOCUS, 4(10), 5517-5526.

[2] F. L. de Souza, L. O. Martins de Andrade, A. Sarto Polo (2013) Nanomaterials for Solar Energy Conversion: Dye-Sensitized Solar Cells Based on Ruthenium (II) Tris-Heteroleptic Compounds or Natural Dyes, DOI: 10.1007/978-3-642-31736-1_2, Springer-Verlag Berlin Heidelberg , 49-80.

[3] S.Pelemiš , I. Hut (2013) Nanotechnology Materials For Solar Energy Conversion, Contemporary Materials (Renewable Energy Sources), IV-2, UDK 66.017/.018:697.514, doi: 10.7251/ COMEN1302145P , 145-151.

[4] E.Serrano, G. Rus, J. García-Martínez (2009) Nanotechnology for sustainable energy,Renewable and Sustainable Energy Reviews, 13(9), 23732384.

[5] M. Zach, C. Hagglund, D. Chakarov, B. Kasemo (2006) Nanoscience and nanotechnology for advanced energy systems, ScienceDirect, Current Opinion in Solid State and Materials Science 10, 132-143.

[6] P.Christopher, D.B.Ingram, S.Linic (2010) Enhancing Photochemical Activity of Semiconductor Nanoparticles with Optically Active Ag Nanostructures: Photochemistry Mediated by Ag Surface Plasmons, J.Phys. Chem. C, 114, 9173-9177.

[7] B. Neltner, B.Peddie, A.Xu, W.Doenlen, K.Durand, D.S.Yun, S.Speakman, A.Peterson, A.Belcher (2010) Production of Hydrogen Using Nanocrystalline Protein-Templated Catalysts on M13 Phage. ACS Nano, 4, 3227-3235.

[8] P. Yianoulis, M. Giannouli (2008) Thin Solid Films and Nanomaterials for Solar Energy Conversion and Energy Saving Applications, Journal of Nano Research Vol. 2 (2008), Online available since 2008/Aug/07 at www.scientific.net Trans Tech 
Publications, Switzerland, doi:10.4028/www.scientific.net/JNanoR.2.49, 44-60.

[9] R.T.Ross, A.J. Nozik (1982) Efficiency of hot-carrier solar energy converters. Journal of Applied Physics, 53(5), 3813-3818.

[10] M. S. A. Abdel-Mottaleb, Frank N"uesch, M.S. Mohamed, A. Abdel-Mottaleb (2009) Solar Energy and Nanomaterials for Clean Energy Development, Hindawi Publishing Corporation International Journal of Photoenergy, Volume 2009, Article ID 525968, 2 pages, doi:10.1155/2009/525968

[11] B.O'Regan, M.Gra"tzel (1991) A low-cost, highefficiency solar cell based on dye-sensitized colloidal TiO2 Films, Nature, 353-737.

\section{IZVOD}

\section{NANOMATERIJALI I NANOTEHNOLOGIJE ZA PROIZVODNJU ODRŽIVE ENERGIJE}

Upotreba nanotehnologija u cilju razvijanja načina proizvodnje održive energije je jedan od najznačajnijih izazova 21 veka. Izazov je dizajnirati, sintetizovati i izvršiti karakterizaciju novih funkcionalnih nanomaterijala kontrolisanih veličina, oblika i/ili struktura. Nanotehnologija danas privlači punu pažnju ne samo akademske zajednice, već i investitora, vlada i privrede a radi izgradnje i ostvarivanja velikih očekivanja.

Ovaj rad istražuje moguću primenu nanotehnologija za nove $i$ unaprijeđene metode pretvaranja energije, uvažavajući potrebe naše sredine. Njihova je jedinstvenost u tome što imaju mogućnost da fabrikuju nove structure na atomskom nivou, kao što su već proizvedeni novi materijali $i$ uređaji sa mogućnošću visoko potencijalne primene u mnogo oblasti. Fokus je na bitnoj ulozi nanomaterijala, pripremi i karakterizaciji nekih nanomaterijala za proizvodnju održive energije, tankoslojnih solarnih ćelija u tehnologiji proizvodnje energije vodonikom.

Ključne riječi: solarna energija, konverzija energije, tankoslojne solarne ćelije, vodonik

Naučni rad

Rad primljen 11.04. 2015.

Rad prihvaćen 09. 06. 2015.

Rad je dostupan na sajtu: www.idk.org.rs/casopis 